\title{
Estimation of the Water Balance in the Basin of Wadi Al Hassa
}

\author{
Dr Talib Hamdallah Almassarweh \\ Dr. Shatha Hussein Rawashdeh \\ University Alhussein Ben Talal
}

doi: 10.19044/esj.2016.v12n35p403 URL:http://dx.doi.org/10.19044/esj.2016.v12n35p403

\begin{abstract}
This study addresses the estimation of water balance in the basin of Wadi Al Hassa through the analysis of climatic elements that controls water balance. The study made use of the monthly data of rainfall and temperatures between the period of 1980 to 2015 at the various stations of the study area (Al Hassa, Jurf Ed Darawish, Prince Hassan Nursery (Abur), and Almazar). This study relied on the model of Thornthwaite and Madre (TM) to identify the general water situation in the basin and to determine the areas of water surplus and shortage in the study areas. The study showed that most of the area suffering from water shortage had reach its peak in July and August, where it drained the soil of an aqueous stock water. Aqueous stock water year is divided into: 1) The season of a water surplus that starts from January until March. In this season, the soil takes the moisture they lost during the dry season. 2) The water shortage season starts from April until November. During this season, the amount of the monthly evaporation exceeds the amount of precipitation.
\end{abstract}

Keywords: Basin, evaporation, water resources, hydrological, moisture

\section{Introduction}

Jordan is located in semi-arid climatic region. Jordan is one of the world's poorest countries in water resources. It is well known that the water resources available for use in Jordan continue to drop as a result of increased demand on water resources. Hence, the importance of surface and underground water resources, which is one of the most important issues that is affecting the Hashemite Kingdom of Jordan, cannot be overemphasized. This, however, is due to diminishing quantities, scarcity, and depletion of water resources. Jordan's sources of water available in 2011 was estimated at 800 million cubic meters, while water demand reached 1,100 million cubic meters. The demand on water is expected to rise by year 2020 up to 1400 
million cubic meters (The Ministry of Water and Irrigation, 2013). The per capita water reached annually at the present time is about $145 \mathrm{~m} 3$, while per capita in 1946 is about $3600 \mathrm{~m} 3$ (USAID, 2010). Thus, this shows that Jordan is suffering from water shortage.

The study of water balance has become a trend which is related to climate studies. Hydrological and agricultural projects have great degree of importance for Jordan, given their importance in the development processes and ways of investment. Thus, this requires a variety of studies to identify aquifers and how regeneration and style extraction is embarked upon, particularly in arid and semi-arid regions. Such a study would provide the decision-maker the decision needed to meet those conditions through the construction of dams on valleys. This, however, is used to hold the water and groundwater recharge information, and the search for alternatives and means. This is with the aim of meeting the population requirements and reducing negative environmental impacts.

It is noted that the water balance studies has gone unheeded. Researchers note that it is one of the vital topics that are related to economic and agricultural activity. The reason for this is due to a lack of climate data and the amount of moisture and field capacity, and the point of wilting in the climatic stations palaces apparatus in addition to the lack of experience by the researchers.

Therefore, felt researcher, who are studying water balance in the basin of Wadi Al Hassa are one of the most limited water basins in the size of its water resources. This is with regards to its great importance on economic activity. However, the climatic elements are as important as the natural components of the environment in shaping the development plans.

\section{Study Problem}

The study problem emanates from the fact that the region suffers from a significant water shortage, which has become a reality in Jordan. As a result, most of the hydrological basins, as well as poor management of water resources, and the study area suffers from the impact of human factors, such as: population growth, increasing water needs, as well as the expansion of agriculture irrigation. This, therefore, results in an increased water consumption and pressure on groundwater and population growth which accompanied the demand for water. Therefore, there is a need to study the water balance in the basin of Wadi Al Hassa. This is accomplished by checking for rain water resources, hydrological Data accuracy, evaporation, runoff, and the study of changes in hydrological circumstances. The reason for that is due to the scarcity of water in comparison with the basin area.

The study attempts to answer the following questions: 
a. Does the water balance vary spatially and temporally in the study area?

b. Does the natural elements of the environment affect the actual storage of soil moisture in its field capacity and the study area spatially?

c. What is the amount of underground water reserves in the study area?

d. What is the relationship between rainfall and runoff?

\section{Hypotheses}

However, we assumed the following hypothesis:

1. There is a relationship between rainfall and runoff.

2. There is a variation in the amount of soil moisture in the basin of Wadi Al Hassa from one place to another and from time to time, as humidity increases and as we head towards the north-west of the basin.

3. There is a relationship between the amount of rain falling on the basin and the soil texture, soil moisture, and its field capacity in the study area.

\section{Objectives of the Study}

The study of water resources in the basin of Wadi Al Hassa is very important for the limited water resources in light of population growth for the region. Here, the average annual rainfall is not more than $150 \mathrm{~mm}$.

The study seeks the following objectives:

1. Analysis of the climatic factors that are related to the water balance in the basin.

2. Knowledge of spatial variation of water balance in the study area of separation to another and from one place to another.

3. Locate surplus and deficit water in the study area.

4. Take advantage of the results of this study in the development of plans and development programs in the field of agricultural activity and water harvesting.

\section{The Study Area Location}

The study area, basin of Wadi Al Hassa, in the southeastern part of the Hashemite Kingdom of Jordan extends into three governorates of Karak, Tafileh, and Maan between longitudes $\left(35^{0}, 18,25\right)\left(36^{0}, 25,68\right)$ East and between the Latitudes $(30,33,07)\left(31^{0}, 03,44\right)$.

Figure (1) shows a basin area (2506.61 km 2). The north Basin extends to the eastern parts (eastern plateau) with low gradient across the area extending west desert road. Here, the acceleration descends into the estuary at the Dead Sea.

The valleys of the basin are part of the valleys that flow into the Dead Sea, which extends over the edge faults - Erosion of the Jordan Valley. It 
varies in rocks, Morphology, degrees of erosion, and intermittency, which led to the difference in topography and multiple faults systems.

Being characterized by pelvic results in a big difference between the highest level of West jurf Ed Darawish station, southeast Tafeileh (1605 m) above sea level, and the lowest level (322 m) below sea level near the town of Safi. It is characterized by the lands of the basin relief and Ruggedness caused by the high drainage density. Also, it deepens the Stream to the cut surface where there are less slope degrees $\left(5^{\circ}\right)$. Thus, the up gradient in the northern slopes is overlooking the mainstream $\left(11^{\circ}\right)$.

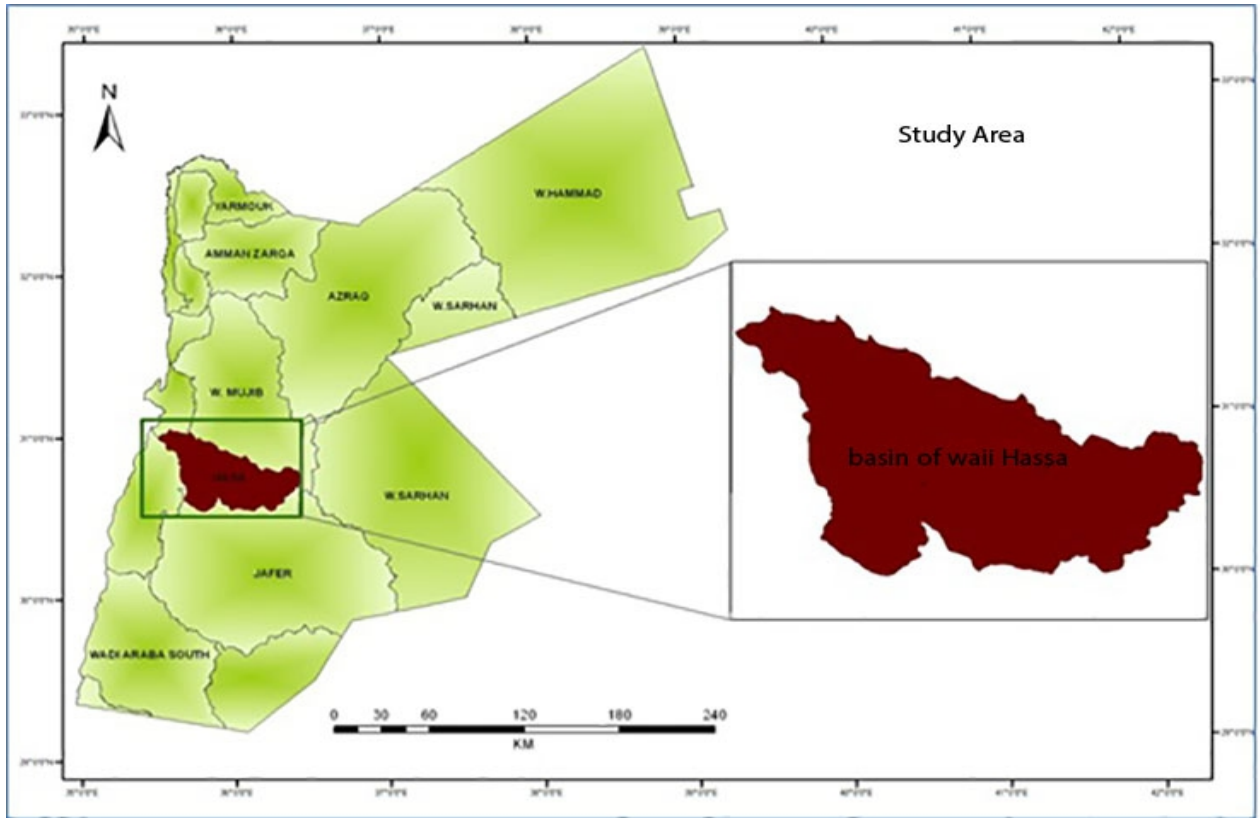

Figure 1. The study area location

In the basin, 6 rainfall stations, due to the proximity of the stations to each other, has been relying on three rainfall stations in the basin and rain station outside the limits of the basin at the north-west of the basin, AL-Mzar station. In addition, stations that monitor rainfall amounts were found in the basin stations evaporation.

Table 1. Rain stations in the basin of Wadi Al Hassa

\begin{tabular}{|c|c|c|c|}
\hline elevation/ $\mathrm{m}$ & Latitude) $\mathrm{Y}($ & Longitude) $\mathrm{X}($ & Station \\
\hline 865 & 414312.2501 & 401220.2413 & Hassa \\
\hline 946 & 395929.6704 & 391463.4657 & jurf Ed Darawish \\
\hline 1251 & 410768.1815 & 375664.2526 & Aabor \\
\hline 1259 & 493688.6467 & 391521.7957 & AL-Mazar \\
\hline
\end{tabular}

Source: researcher based on the Ministry of Water and Irrigation 
Consequently, it was observed that some of the records of the stations were missing based on the level of days. This is with the exception of ALMazar stations which saw continuity in the registry during the period studied, and also station nursery Prince Hassan (Aabor) whose data is available since 1980 . As a result, their data was only adopted since that time until the rain year 2015/2016. The reason for the lack of data was due to the lack of constant maintenance of these stations, or the closure of some stations which do not record rainfall data. Therefore, the researcher has complete lack of all measurement following the modification method and linear correlation stations data. This, therefore, aims to estimate missing precipitation values in some of the stations according to records at the level of other neighboring stations.

Figure 2. Distribution stations

Source: Researcher based on the Ministry of Water and Irrigation Data

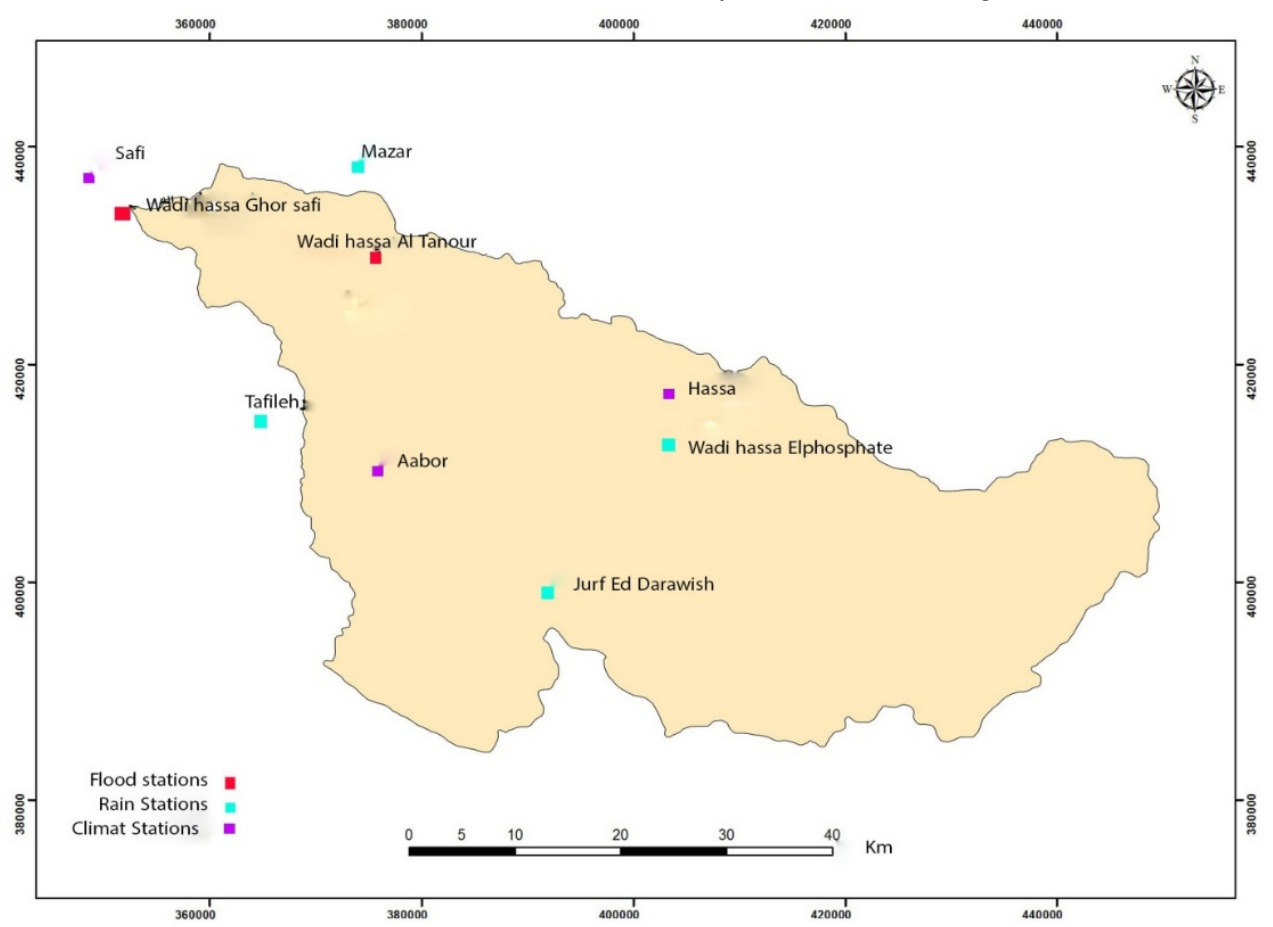

\section{Previous Studies}

The study of Abu- saleem (2009) was on estimating water balance components in the basin of the wadi Hasa using remote sensing applications and model WetSpss. Here, the following was employed: the application of GIS and remote sensing techniques to obtain information on hydrological processes to simulate the water balance elements in the basin of the wadi of Hasa, the development of land use, long-term estimate of the annual rate, and 
the seasonal water balance elements. Thus, this refers to the actual runoff, evaporation, and groundwater recharge.

The study of Al-balawi (2003) was based on a study of hydrological and hydrogeological basin in wadi Wala. I tried to identify the relationship between rainfall and runoff, assess the water balance in the basin area, and determine the groundwater flow system. The method used is the rainfall and runoff actual data analysis, and the average rainfall and coefficient of runoff for the period of 1975 to 2002 was also measured.

Annanzih (1996) conducted a study on the water balance based on rainfall amounts of evaporation and potential evapotranspiration in the basin of the wadi of Karak. Thus, this study addressed the water balance of the basin of the wadi of Karak, based on the estimate transpiration amounts and potential evaporation through the application of some experimental equations on weather stations in the basin. Thus, it has applied three equations. Thornthwait and Khosla, and Khrofh show that the results of these equations as the amount of evaporation and transpiration potential in the basin range (781. $1184.8 \mathrm{~mm}$ / year). These equations also showed that the water year in the basin is divided into separate aqueous surplus from the beginning of December until the end of March. On the other hand, the separation of water shortage runs from the beginning of April until the end of November.

Jasrotia et al. (2009) opines that the recruitment of the results that have been obtained from the water balance calculation is used to determine the water harvesting systems sites in Jammu Himalaya region of India. Also, it is used (R.S \& GIS) to produce maps of land use and other maps. Therefore, the map was derived based on the potential flow-derived measurements of the water balance calculation. In addition, it is used for identifying suitable locations at the end of the harvest rainwater through thematic maps.

AL-Jabri et al. (2009) determines the water balance of the basin of the wadi Su'd in the West Bank by using the method of SCS- CN. Here, the researchers use the results to estimate runoff, in addition to the monthly rate of evaporation (see the page on calculation to estimate the water balance rate).

Victoria et al. (2007) shows the importance of using model (TM) as a model for integration with the climate (GIS) to estimate the monthly water balance of the basin of the river (Ji-Parana) located West of the state of Amazonas. Also, it relies on visuals satellites high discriminatory power and also adopted a researcher in the study based on a model (TM) for the preparation of water balance of the basin of Hasa. As a result, the water balance has a significant importance and influence in the decision-making criteria in determining the spatial probability of water harvesting. 


\section{Methodology}

The study relied on the use of the experimental method for the analysis of climatic elements associated with the water balance.

Researcher adopted the water balance account in the study area based on the modified equation Thornthwait for the year 1957. This relies on rainfall data, and the degrees of heat and monthly maps of the soil. In addition, water balance is calculated based on a combination of the following variables:

1. Potential Evapotranspiration (PET) through the following equation:

$$
\underset{1957 \text { ) }}{\mathrm{PET}}=1.6 \times \mathrm{C} \times\left(10 \times \frac{\mathrm{T}}{\mathrm{I}}\right)^{\mathrm{a}} \quad \text { (thornthwait \& mather, } 1955 \text {, }
$$

Where:

PET= Potential Evapotranspiration (mm month-1)

$\mathrm{T}=$ Mean monthly temperature

$\mathrm{C}=$ The annual heat index for the 12 months in a year $\mathrm{C}=\left(\frac{\mathrm{M}}{\mathbf{3}_{0}}\right) \times\left(\frac{\mathrm{D}}{12}\right)$
Where:

$\mathrm{M}=$ The number of days in the month

$\mathrm{D}=$ The monthly mean daily duration

I= The year heat index.

i $\sum \mathrm{I}=$

$=$ The monthly heat index. $\mathrm{i}$

$\mathrm{I}=[\mathrm{T} / 5]^{1.514}$ )

$\mathrm{T}=$ Where the average monthly temperature $(\mathrm{m})$

For lack of data for temperatures to Station, Mazar station jurf Ed Darawish lost. Researcher depends on the temperature of the station. This is due to the proximity of the two stations from each other, no differences in climate between them, and based on the decrease in temperature with height between the two stations rate.

Thermal context function (a) and the ability through is given as:

$\left.\left.\mathrm{a}=\left(6.75 \times 10^{-7} \times \mathrm{I}^{3}\right)-\left(7.71 \times 10^{-5}\right) \times \mathrm{I}^{2}\right)+\left(1.792 \times 10^{-2} \times \mathrm{I}\right)+0.49239\right)$

2. Estimating the difference between Potential Evapotranspiration and precipitation (P-PET), appreciation surplus water, and water deficit where $\mathrm{P}$ represents the monthly average rainfall.

3. Accumulated potential Wetness Loss (APWL). The cumulative estimate Accumulated potential Wetness Loss each month (P-PET) If the rainfall is more than the underlying rate of Potential Evapotranspiration $\mathrm{PET}<\mathrm{p}$ Be $(\mathrm{APWL})=0$ In wet months. They are calculated (APWL) when the $\mathrm{PET}>\mathrm{p}$ in any of the dry months.

4. This is the real inventory estimation of the actual storage of soil moisture (SM): Where

$\mathrm{SM}=\mathrm{AWC} \times \mathrm{e}^{(\mathrm{APWL} / \mathrm{AWC})}$ 
Constant e = 2.78; Also AWC is known as Field capacity in the soil.

The researcher calculates the field capacity, depending on the characteristics of the soil in the study area.

Soil Texture: The proportion of each of mud, sand and silt, which were obtained from soil surveys carried out by the Ministry of Agriculture in 1993.

The Proportion of Organic Matter: This was found in the soil obtained by a researcher from the surveys and the Ministry of Agriculture in 1993.

Coarse Fragments: Coarser soil particles were obtained from surveys of the Ministry of Agriculture in 1993.

As a first step, the researcher calculates Bulk Density Depending on the model One Dimensional soil water Dynamics model (SWDM - 1D) which was developed by Soleman (2006) in the College of Agriculture at the University of Jordan. However, this depends on the ratio of sand, clay, and organic matter. In a second step, the researcher calculates the Field capacity which depends on the ratio of sand, mud, the percentage of organic matter, the roughness of soil particles, and the density of bulk. In the third step, Wilting Points depending on the ratio of sand, organic matter, soil particles roughness, density of bulk, and field capacity was calculated.

5. Changes in soil moisture can calculate the change in soil moisture for the months of the year. This is possible by introducing soil moisture in the month of soil moisture in the previous month, as well as the months of the year.

6. The Actual Evaporation (AET). If the change is greater than zero soil moisture $(\Delta \mathrm{SM}>0), \mathrm{Be} A E T=\mathrm{PET}$. If the change in the soil moisture is less than zero $(\Delta \mathrm{SM}<0), \mathrm{AET}=(\Delta \mathrm{SM} \times-1)+\mathrm{P}$.

7. The Water Deficit (DEF) Through DEF = PET- AET.

8. The Water Surplus: This is an estimate of water surplus for the months in which the soil moisture field is equal to the capacity available. In months where there are equally soil moisture with a field capacity, they suffer from water shortage. Sur $=$ P- PET.

9. Water Runoff: Av.Runoff = Surmonth + Surprevious Month; thus the water is flowing to the rest of the months. Runoff month $=\mathrm{A}$. V Runoff previous month + Surmonth.

Consequently, the remaining portion of the water is exposed to either leaking or they are being held in the soil (Thornthwait \& mather, 1955 1957).

\section{Elements of the Water Balance}

Water Balance is considered relevant in assessing the amount of the surplus or deficit of water, especially in arid and semi-arid regions. This ails 
those areas of water shortage due to the limited surface water resources, low amounts of rainfall, and erratic rainfall from year to year.

Therefore, it is necessary to estimate the water balance in the study area because it is located within the dry region to determine the water deficit amounts, the amount of vegetation needs of irrigation water, and putting development plans in place to take advantage of running water, the excess water and reduce wastage, and in the understanding of water hydrology in the region.

The Mean Water Balance: This is the dynamic balance of the quantities of water added through rain or irrigation, and the amount of water evaporation from the soil, plants and runoff (Shehadeh, 1983). It also refers to the realised water balance from rainfall, the rate of Potential Evapotranspiration, and runoff. Therefore, Tables 2, 3, 4, and 5 shows the elements of water balance in the basin.

1. Potential Evapotranspiration (PET): This is the amount of water lost from surface water to water-saturated soil, and it affects the amount of evaporation of soil type and the amount of water in the soil and plants.

The Tohrnthwaite is of great benefit to estimate the water balance of small and large basins space equation. Also, it can be applied to areas where precise data are not available for field capacity of the soil, the quality of the vegetation, and the depths where it is extended.

It is possible to reach results close to the truth, even with the lack of such data in the study area. If a researcher adopts the formula, it is possible to reach results close to the truth. Also, he/she can estimate the Potential Evapotranspiration of the following equation: $\mathrm{PET}=1.6 \times \mathrm{c} \times(10 \times \mathrm{T} / \mathrm{I})^{\mathrm{a}}($ Thornthwait \& mather, 1955 , 1957)

2. To estimate Water Surplus and Water Deficit ( P-PET )

Table 2. Elements of AL-Mazar station water balance

\begin{tabular}{|c|c|c|c|c|c|c|c|c|c|c|c|c|c|}
\hline Month & Jan & Feb & Mar & Apr & May & June & Jul & Aug & Sep & Oct & Nov & Dec & $\begin{array}{c}\text { Yea } \\
r\end{array}$ \\
\hline $\mathrm{T}$ & 4.80 & 4.86 & 7.51 & $\begin{array}{c}12.4 \\
3\end{array}$ & $\begin{array}{c}16.0 \\
9\end{array}$ & $\begin{array}{c}18.4 \\
2\end{array}$ & $\begin{array}{c}20.1 \\
4\end{array}$ & $\begin{array}{c}20.1 \\
4\end{array}$ & $\begin{array}{c}18.5 \\
0\end{array}$ & $\begin{array}{c}15.6 \\
9\end{array}$ & $\begin{array}{c}10.4 \\
1\end{array}$ & 6.17 & 12.9 \\
\hline i & 0.9 & 1.0 & 1.9 & 4.0 & 5.9 & 7.2 & 8.2 & 8.2 & 7.2 & 5.6 & 3.0 & 1.4 & 54.6 \\
\hline $\mathrm{a}$ & 0.51 & 0.51 & 0.53 & 0.56 & 0.60 & 0.62 & 0.64 & 0.64 & 0.62 & 0.59 & 0.55 & 0.52 & 0.57 \\
\hline PET & 1.5 & 1.5 & 1.9 & 2.6 & 3.0 & 3.2 & 3.4 & 3.4 & 3.2 & 2.9 & 2.3 & 1.7 & 30.5 \\
\hline c & 0.89 & 0.86 & 1.03 & 1.08 & 1.19 & 1.20 & 1.21 & 1.15 & 1.03 & 0.98 & 0.88 & 0.87 & \\
\hline $\begin{array}{c}\mathrm{PET} / \mathrm{m} \\
\mathrm{m}\end{array}$ & 13 & 13 & 20 & 28 & 35 & 38 & 41 & 39 & 33 & 29 & 20 & 15 & 324 \\
\hline $\mathrm{p} / \mathrm{mm}$ & $\begin{array}{c}73.9 \\
8 \\
\end{array}$ & $\begin{array}{c}82.8 \\
6 \\
\end{array}$ & $\begin{array}{c}48.4 \\
6 \\
\end{array}$ & $\begin{array}{c}13.1 \\
2 \\
\end{array}$ & 2.95 & 0.0 & 0.0 & 0.0 & 0.0 & 4.01 & $\begin{array}{c}15.8 \\
0 \\
\end{array}$ & $\begin{array}{c}52.8 \\
3 \\
\end{array}$ & $\begin{array}{c}294 . \\
0\end{array}$ \\
\hline P-PET & 60.8 & 70.0 & 28.7 & $\begin{array}{c}- \\
14.5 \\
\end{array}$ & $\begin{array}{c}- \\
32.3 \\
\end{array}$ & $\begin{array}{c}- \\
38.4 \\
\end{array}$ & -40.7 & -38.7 & -33.0 & -24.6 & -4.5 & 37.9 & $\begin{array}{c}- \\
29.6 \\
\end{array}$ \\
\hline APWL & 0.0 & 0.00 & 0.0 & $\overline{14.5}$ & $\begin{array}{c}- \\
46.8\end{array}$ & $\begin{array}{c}- \\
85.2\end{array}$ & $\begin{array}{c}- \\
126 . \\
0\end{array}$ & $\begin{array}{c}- \\
164 . \\
7\end{array}$ & $\begin{array}{c}- \\
197 . \\
8\end{array}$ & $\begin{array}{c}- \\
222 . \\
4\end{array}$ & $\begin{array}{c}- \\
226 . \\
9\end{array}$ & 0.0 & \\
\hline
\end{tabular}


Table 3. Elements of Aabor station water balance

\begin{tabular}{|c|c|c|c|c|c|c|c|c|c|c|c|c|c|}
\hline Month & Jan & Feb & Mar & Apr & May & June & Jul & Aug & Sep & Oct & Nov & Dec & Year \\
\hline T & 7.12 & 7.24 & 12.28 & 15.86 & 19.35 & 23.02 & 24.26 & 24.37 & 22.31 & 19.14 & 13.22 & 8.90 & 16.4 \\
\hline $\mathrm{i}$ & 1.7 & 1.8 & 3.8 & 5.8 & 7.7 & 10.9 & 11.3 & 11.4 & 9.18 & 7.6 & 4.3 & 1.4 & 77.2 \\
\hline $\mathrm{a}$ & 0.52 & 0.52 & 0.56 & 0.59 & 0.63 & 0.68 & 0.69 & 0.69 & 0.65 & 0.63 & 0.57 & 0.52 & 0.60 \\
\hline $\mathrm{PET}$ & 1.5 & 1.5 & 2.1 & 2.5 & 2.8 & 3.2 & 3.2 & 3.2 & 3.0 & 2.8 & 2.2 & 1.5 & 29.5 \\
\hline $\mathrm{c}$ & 0.89 & 0.86 & 1.03 & 1.08 & 1.19 & 1.20 & 1.21 & 1.15 & 1.03 & 0.98 & 0.88 & 0.87 & \\
\hline PET/mm & 14 & 13 & 22 & 27 & 33 & 37 & 39 & 37 & 31 & 27 & 19 & 15 & 314 \\
\hline $\mathrm{p} / \mathrm{mm}$ & 51.65 & 46.32 & 39.32 & 10.26 & 2.83 & 0.0 & 0.0 & 0.0 & 0.0 & 3.89 & 12.20 & 33.05 & 199.5 \\
\hline P-PET & 38.2 & 33 & 17.8 & -16.4 & -30.1 & -38.1 & -39 & -37.2 & -30.6 & -23.1 & -7.2 & 19.6 & -113.2 \\
\hline APWL & 0.0 & 0.00 & 0.00 & -16.4 & -46.5 & -84.63 & -123.6 & -160.77 & -191.34 & -214.47 & -221.7 & 0.00 & \\
\hline
\end{tabular}

Table 4. Elements of jurf Ed Darawish station water balance

\begin{tabular}{|c|c|c|c|c|c|c|c|c|c|c|c|c|c|}
\hline Month & Jan & Feb & Mar & Apr & May & June & Jul & Aug & Sep & Oct & Nov & Dec & Year \\
\hline T & 7.74 & 9.44 & 11.91 & 17.08 & 20.86 & 23.24 & 24.78 & 24.85 & 23.40 & 19.71 & 14.17 & 9.32 & 17.2 \\
\hline $\mathrm{i}$ & 1.9 & 2.6 & 3.7 & 6.4 & 8.7 & 10.2 & 11.3 & 11.3 & 10.3 & 8.0 & 4.8 & 2.6 & 82.0 \\
\hline $\mathrm{a}$ & 0.53 & 0.54 & 0.56 & 0.60 & 0.64 & 0.67 & 0.69 & 0.69 & 0.67 & 0.63 & 0.58 & 0.54 & 0.61 \\
\hline $\mathrm{PET}$ & 1.5 & 1.7 & 2.0 & 2.5 & 2.8 & 3.0 & 3.1 & 3.1 & 3.0 & 2.7 & 2.2 & 1.7 & 29.7 \\
\hline $\mathrm{c}$ & 0.89 & 0.86 & 1.03 & 1.08 & 1.19 & 1.20 & 1.21 & 1.15 & 1.03 & 0.98 & 0.88 & 0.87 & \\
\hline PET/mm & 14 & 15 & 21 & 27 & 34 & 36 & 38 & 36 & 31 & 27 & 20 & 15 & 313 \\
\hline $\mathrm{p} / \mathrm{mm}$ & 17.12 & 11.77 & 15.90 & 5.04 & 0.0 & 0.0 & 0.0 & 0.0 & 0.0 & 2.36 & 8.60 & 15.95 & 76.7 \\
\hline P-PET & 3.4 & -3.2 & -4.8 & -22.0 & -33.7 & -36.3 & -38.0 & -36.2 & -31.3 & -24.4 & -11.1 & 0.9 & -236.6 \\
\hline APWL & 0.0 & -3.2 & -8.0 & -30.0 & -63.7 & -99.9 & -138.0 & -174.2 & -205.4 & -229.8 & -240.9 & 0.0 & \\
\hline
\end{tabular}

Table 5. Elements of Hasa station water balance

\begin{tabular}{|c|c|c|c|c|c|c|c|c|c|c|c|c|c|}
\hline Month & Jan & Feb & Mar & Apr & May & June & Jul & Aug & Sep & Oct & Nov & Dec & Year \\
\hline $\mathrm{T}$ & 8.38 & 10.08 & 12.55 & 17.72 & 21.5 & 23.88 & 25.42 & 25.49 & 24.04 & 20.35 & 14.81 & 9.96 & 17.8 \\
\hline $\mathrm{i}$ & 2.2 & 2.9 & 4.0 & 6.8 & 9.1 & 10.7 & 11.7 & 11.8 & 10.8 & 8.4 & 5.2 & 2.8 & 86.3 \\
\hline $\mathrm{a}$ & 0.53 & 0.54 & 0.56 & 0.61 & 0.65 & 0.68 & 0.69 & 0.69 & 0.68 & 0.64 & 0.58 & 0.54 & 0.62 \\
\hline $\mathrm{PET}$ & 1.6 & 1.8 & 2.0 & 2.5 & 2.8 & 3.0 & 3.1 & 3.1 & 3.0 & 2.7 & 2.2 & 1.7 & 29.7 \\
\hline $\mathrm{c}$ & 0.89 & 0.86 & 1.03 & 1.08 & 1.19 & 1.20 & 1.21 & 1.15 & 1.03 & 0.98 & 0.88 & 0.87 & \\
\hline PET/mm & 1.4 & 1.5 & 2.1 & 2.7 & 3.4 & 3.6 & 3.8 & 3.6 & 3.1 & 2.7 & 2.0 & 1.5 & 31 \\
\hline $\mathrm{p} / \mathrm{mm}$ & 14 & 15 & 21 & 27 & 34 & 36 & 38 & 36 & 31 & 27 & 20 & 15 & 313 \\
\hline $\mathrm{P}-\mathrm{PET}$ & 10.750 & 6.100 & 9.200 & 1.700 & 0.500 & 0.0 & 0.0 & 0.0 & 0.0 & 2.200 & 7.300 & 10.000 & 47.8 \\
\hline APWL & -3.2 & -9.0 & -11.6 & -25.3 & -33.0 & -36.1 & -37.8 & -36.0 & -31.1 & -24.5 & -12.4 & -5.2 & -265.2 \\
\hline $\mathrm{T}$ & -3.2 & -12.07 & 23.67 & -48.97 & -81.97 & -118.07 & -155.87 & -191.87 & -222.97 & -247.47 & -259.87 & -265.07 & \\
\hline
\end{tabular}

\section{Accumulated Potential Wetness Loss (APWL)}

If the rainfall is more than the rate of evaporation - transpiration latent $(\mathrm{PET}<\mathrm{P})$, then the surplus (saturation) is added to the difference of the soil moisture to the point of arrival of soil saturation (field capacity). When the change is zero, and when the evaporation latent is more than precipitation (PET $>\mathrm{P})$, then the deficit, and the change is decreasing to the point of wilting point. Here, it becomes the Accumulated potential Wetness Loss which is also zero.

That is, it is zero in the months characterized by a water surplus. Also, it starts an account (AWL) at the beginning of months, which is characterized by a water deficit, as shown in the table number $2,3,4$, and 5 . 
The researcher believes that APWL values and a clear indication of the available soil moisture, leads to a runoff in the months they do not suffer from a deficit in the accumulation of moisture in the soil. Thus, this is because of their importance in agriculture to lay the foundations of development and agricultural programs in irrigation, and to determine the necessary amount of water process for irrigation and timely. This, however, is in addition to the possibility of the creation of earth dams to hold the water e.g. the Mazar stations and Aabor stations.

\section{The Actual Storage of Soil Moisture (SM)}

Depending on the field capacity and the percentage of sand and the density of the block, we have identified the field capacity of the soil and the point of wilting in the basin of the wadi Hasa. This depends on the different type of soil in terms of sand, clay, and silt and organic matter proportion and composition. Furthermore, moisture for plants depends on the texture and thickness of the soil, as well as its depth. Also, it affects the amount of runoff and the amount of groundwater. The soil which absorbs water decreases with the increase in available moisture to the soil. If the soil has not reached the degree of saturation, it does not get a surface or underground water flow.

When the rains fall and after the soil saturation begins, then the water flows into the soil, filled the pores, and voids the soil. When filled with water, the water flows on the surface and then the soil is saturated with the water. This, however, is called capacitive field. It relies on the field capacity of the soil texture. Sandy soil is longer and its field capacity is low due to the quick saturation. For sandy soil, water seeps through the gaps quickly, unlike the clay soil. In addition, the field capacity is measured by water in the soil in comparison with the weight of the saturated soil.

As a result of the soil basin desert, it has the ability to retain a few water, while clay soil spread in the areas covered by the Mazar station. In addition, the soil produced by the Ministry of Agriculture maps and its field capacity in the basin of the valley Hasa is as shown in Table 6.

Table 6 . Field capacity of the stations of Wadi Hasa

\begin{tabular}{|c|c|}
\hline Field capacity & Station \\
\hline 130 & Mazar \\
\hline 100 & Aabor \\
\hline 80 & jurf Ed Darawish \\
\hline 70 & Hassa \\
\hline
\end{tabular}

The researcher calculates the soil moisture as shown in Table 7. Also, the researcher extracted the change in available soil moisture by introducing soil moisture for the month, followed by bringing values cationic to indicate what has been added to the soil moisture values and the negative impact on the amount of moisture lost by evaporation. 
Table 7. The Actual storage of Soil moisture and the change in the Actual Soil moisture of Wadi Hasa stations

\begin{tabular}{|c|c|c|c|c|c|c|c|c|c|c|c|c|c|c|c|}
\hline \hline Month & Jan & Feb & Mar & Apr & May & June & Jul & Aug & Sep & Oct & Nov & Dec & Station \\
\hline \hline SM & 200 & 200 & 200 & 185.71 & 157.43 & 129.36 & 105.04 & 86.168 & 72.775 & 64.169 & 63 & 200 & -1.47 & 137.3 \\
\hline SM $\Delta$ & 0.0 & 0 & 0 & 14.29 & -28.28 & -28.07 & -24.33 & -18.89 & -13.39 & -8.61 & -1.47 \\
\hline AET & 13 & 13 & 20 & 28 & 31 & 28 & 24 & 19 & 13 & 13 & 17 & 15 \\
\hline DEF & 0.0 & 0.0 & 0.0 & 0.0 & 4.0 & 10.3 & 16.4 & 19.9 & 19.7 & 16.0 & 3.1 & 0.0 \\
\hline Sur & 61 & 70 & 29 & 0 & 0 & 0 & 0 & 0 & 0 & 0 & 0 & 0 \\
\hline $\begin{array}{c}\text { Water } \\
\text { Runoff }\end{array}$ & 30 & 50 & 39 & 0 & 0 & 0 & 0 & 0 & 0 & 0 & 0 & 0 \\
\hline \hline SM & 200 & 200 & 200 & 183.92 & 157.68 & 129.76 & 106.32 & 87.92 & 75.2 & 66.81 & 64 & 200 & \\
\hline SM $\Delta$ & 0.0 & 0 & 0 & 16.08 & -26.23 & -27.93 & -23.44 & -18.39 & -12.72 & -8.38 & -2.42 & 135.61 \\
\hline AET & 13 & 13 & 22 & 27 & 29 & 28 & 23 & 18 & 13 & 12 & 15 & 13 \\
\hline \begin{tabular}{c} 
DEF \\
\hline Sur
\end{tabular} & 38 & 0.0 & 0.0 & 0.0 & 3.9 & 10.2 & 15.5 & 18.8 & 17.9 & 14.7 & 4.8 & 0.0 \\
\hline $\begin{array}{c}\text { Water } \\
\text { Runoff }\end{array}$ & 19 & 26 & 22 & 0 & 0 & 0 & 0 & 0 & 0 & 0 & 0 & 10 \\
\hline \hline
\end{tabular}

\begin{tabular}{|c|c|c|c|c|c|c|c|c|c|c|c|c|c|c|c|}
\hline \hline Month & Jan & Feb & Mar & Apr & May & June & Jul & Aug & Sep & Oct & Nov & Dec & Station \\
\hline \hline SM & 200 & 196.73 & 191.96 & 171.54 & 144.42 & 119.99 & 98.794 & 82.105 & 69.982 & 61.769 & 58 & 200 & \\
\hline SM $\Delta$ & 0.0 & 3.2713 & 4.7657 & 20.421 & -27.12 & -24.43 & -21.19 & -16.69 & -12.12 & -8.213 & -3.396 & 141.63 \\
\hline AET & 14 & 15 & 21 & 27 & 27 & 24 & 21 & 17 & 12 & 11 & 12 & 15 & 0.0 \\
\hline $\begin{array}{c}\text { DEF } \\
\text { Sur }\end{array}$ & 0.0 & 0.0 & 0.0 & 0.0 & 6.5 & 11.8 & 16.8 & 19.5 & 19.1 & 16.2 & 7.7 & 0 \\
\hline $\begin{array}{c}\text { Water } \\
\text { Runoff }\end{array}$ & 3 & 0 & 0 & 0 & 0 & 0 & 0 & 0 & 0 & 0 & 0 & 0 \\
\hline SM & 2 & 1 & 0 & 0 & 0 & 0 & 0 & 0 & 0 & 0 & 0 & 0 \\
\hline \hline SM $\Delta$ & 200 & 188.05 & 177.24 & 155.75 & 131.55 & 109.4 & 90.165 & 75.008 & 63.983 & 56.456 & 53 & 52 & -1.02 \\
\hline AET & 148.4 & 11.946 & 10.811 & 21.494 & -24.19 & -22.16 & -19.23 & -15.16 & -11.02 & -7.527 & -3.461 & -1.393 \\
\hline DEF & 14 & 15 & 21 & 27 & 25 & 22 & 19 & 15 & 11 & 10 & 11 & 11 \\
\hline Sur & 0.0 & 0.0 & 0.0 & 0.0 & 8.8 & 13.9 & 18.6 & 20.8 & 20.1 & 17.0 & 8.9 & 3.8 \\
\hline $\begin{array}{c}\text { Water } \\
\text { Runoff }\end{array}$ & 0 & 0 & 0 & 0 & 0 & 0 & 0 & 0 & 0 & 0 & 0 & 0 \\
\hline SM & 0 & 0 & 0 & 0 & 0 & 0 & 0 & 0 & 0 & 0 & 0 & 0 \\
\hline \hline
\end{tabular}

5. Changes in The Actual Storage of Moisture: You can calculate Changes in The Actual storage of moisture for the months of the year by introducing The Actual storage of moisture for the previous month. This also goes on for the months of the year.

6.

Evaportranspiration: The researcher calculates the real evaporation according to the following method:

If the change is greater than zero soil moisture $(\Delta \mathrm{SM}>0)$, Be $\mathrm{AET}=\mathrm{PET}$ 
$(\Delta \mathrm{SM}<0)$. If the change in the soil moisture is less than zero $\mathrm{AET}=(\Delta \mathrm{SM} \times-$ $1+\mathrm{P})$ as can be seen in table 7 .

7. Water Surplus

If the amount of rainfall increases the amount of Potential Evapotranspiration, then there will be a water surplus, and it shall take some amount of water to reach the degree of saturation. Also, the remaining portion of the rainwater flows to the ground, while the other part seeps into the ground to feed the groundwater. The actual storage of soil moisture and the equal field of capacity available is considered a water surplus. The variation stations value from month to month is evident from table 7 . In Aabor station, watery surplus of December extends up to the month of March, as well as Mazar station extends to the water surplus of the month of January. Furthermore, surplus water is available in the month of January in Jurf Ed Darawish station. Hasa station suffers from water shortage, while all stations suffer from water shortage for the rest of the months. This, therefore, can be seen in figure 4 .

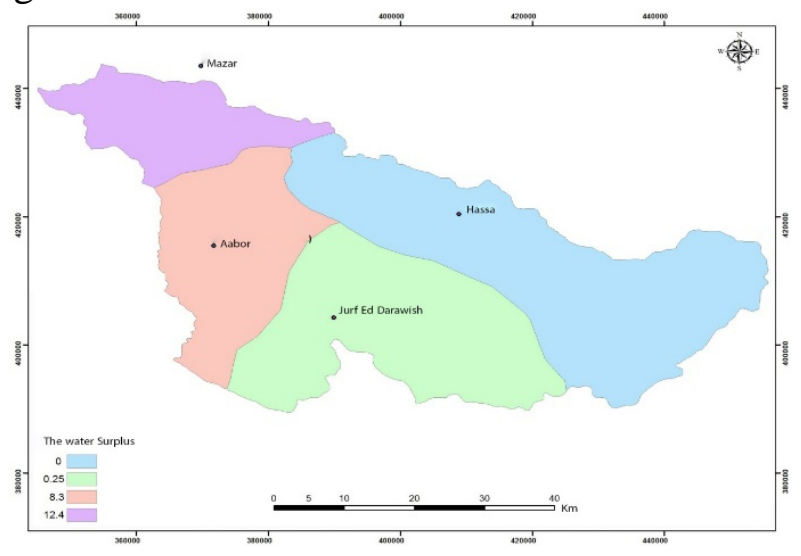

Figure 4. Surplus water in the basin of the wadi Hassa

\section{Water Deficit}

The region suffers from water shortage when the Potential Evapotranspiration is higher than the amount of rainfall. The region suffers from water shortage in the months which are not equal to the actual storage of soil moisture available in the field capacity. This can be seen from figure (5). 


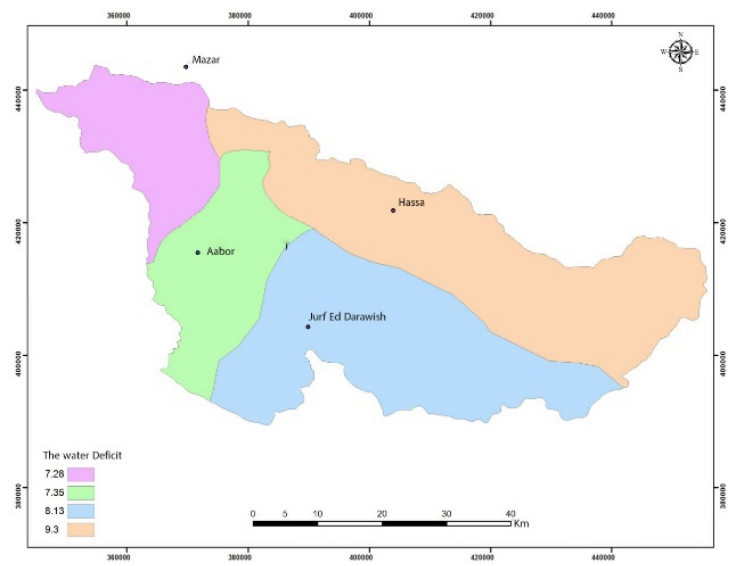

Figure 5. Water Deficit in the basin of the wadi Hassa

\section{Water Runoff}

The researcher calculates the runoff by adding $50 \%$ of the water surplus to the previous month from the surplus of the current month.

Consequently, the estimate of water surplus and the deficit of water and runoff (Table 7) is of paramount importance in determining the rainy ability to bridge the water needs of the region, as well as to determine the possibility of establishing water harvesting projects. It also helps in identifying appropriate locations for such projects in the basin of the wadi Hassa through areas characterized by runoff surface.

\section{Analyzing the Results of Water Balance in the Basin of the Wadi Hassa}

When the water balance accounts for a long period of time, it gives it a great benefit by estimating The Actual storage of moisture during the year. Thus, it determine the periods of experiencing Water Deficit or watery surplus and the occurrence of runoff. Furthermore, we note that the stations that are located on the station Aabor stations is located in areas of high altitudes North-West of the basin. This results to an experience of a water surplus and the occurrence of runoff during the winter. This occurs especially during the period from January until March. Also, the rest of the year, particularly the summer months, are months that Water Deficit rise in evaporation rates and increase soil moisture loss. Thus, this applies to all the stations that represent the basin, especially in the summer months. This was such that the region suffers from water Deficit during the year, especially in the summer months. To achieve the objectives of the study, the assessment of water resources in the basin Wadi Hassa water balance is of immense importance.

To determine the extent of the success of the water projects and the establishment of agricultural projects, it was noted that most of the basin area 
suffer from Water Deficit. The areas that saw water surplus fell in the ranges that average rainfall ranges in between (100-280 mm), marked by the Mazar and Aabor stations. Consequently, Mazar station increases the water surplus for the $155 \mathrm{~mm}$ of not more than the percentage of the area $(11.74 \%)$ of the basin. On the other hand, Aabor station, which ranged from water surplus in between $18-38 \mathrm{~mm}$, comprises of $17.47 \%$ of the figures of the basin area (6, 7, 8. and 9).

Subsequently, this resulted in the expansion of agriculture within these areas and the possibility of water projects. Furthermore, the rest of the large basin areas are desert wasteland strewn with desert shrubs.

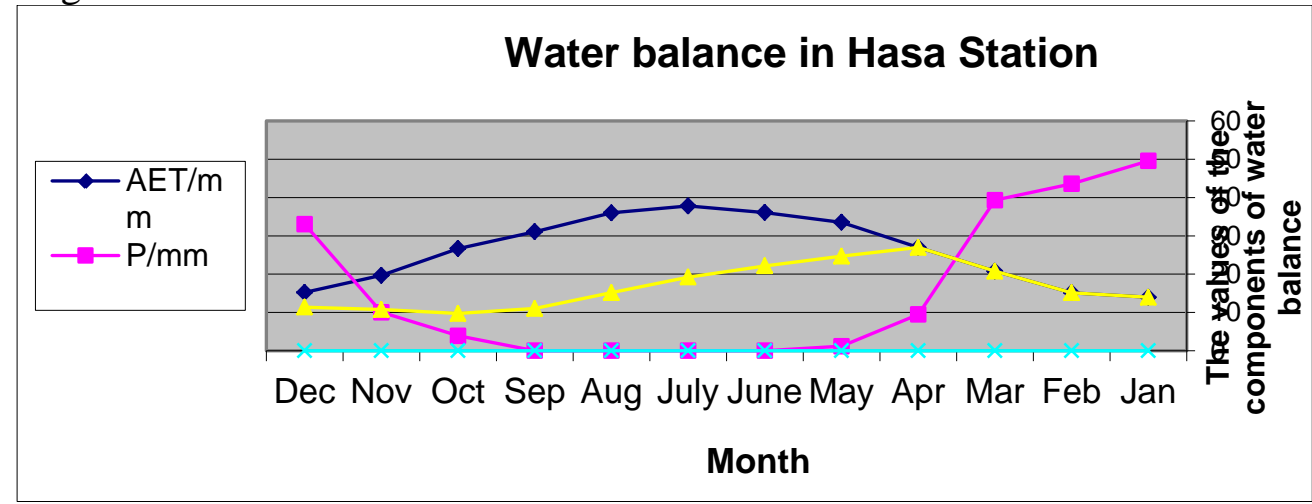

Figure 6. Water balance in Hasa Station

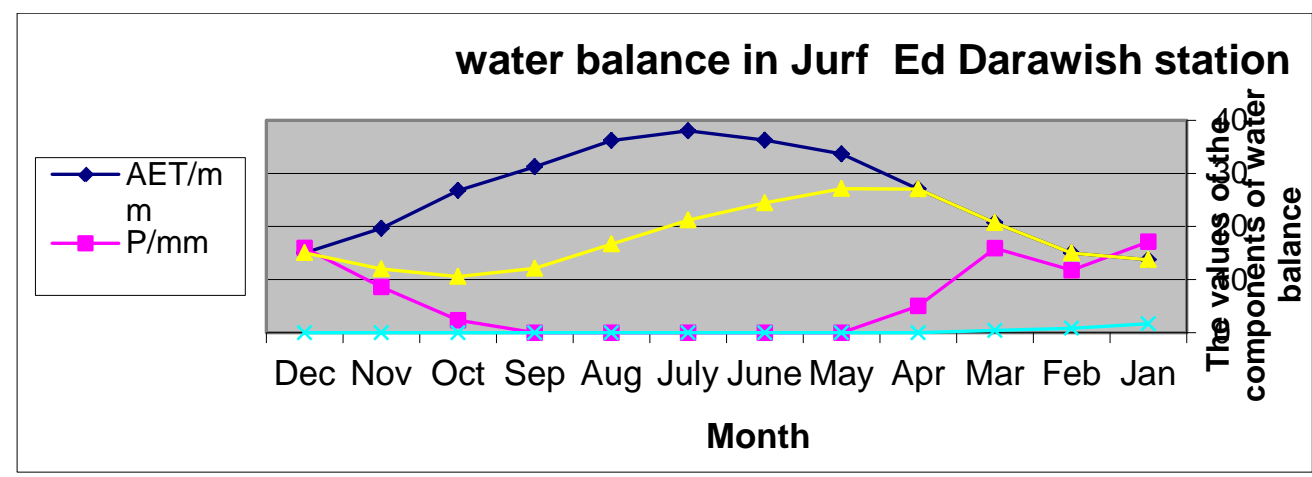

Figure 7. Water balance in Jurf Ed Darawish station 


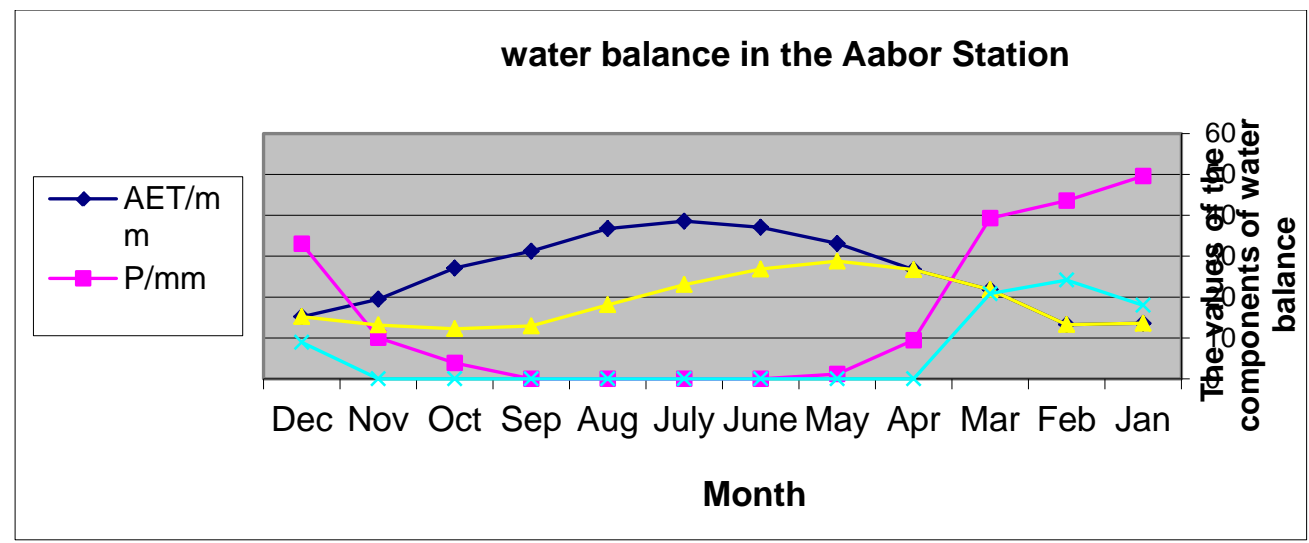

Figure 8. Water balance in the Aabor Station

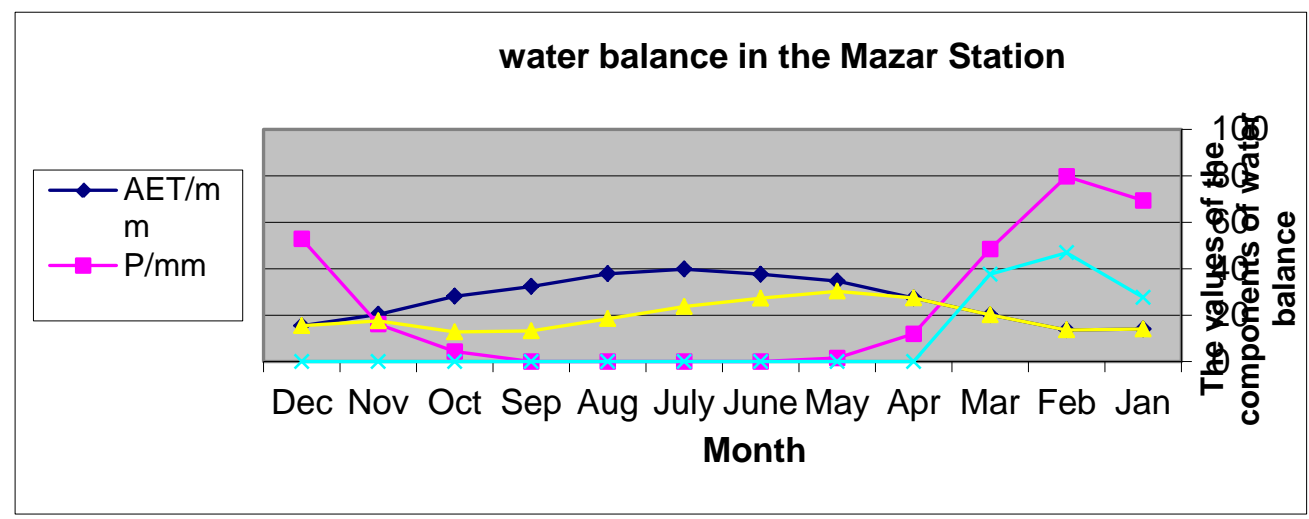

Figure 9. Water balance in the Mazar Station

\section{The Amount of Recharge in the Basin of the Wadi Hassa}

As the rain falls, part of it flows through slopes in the form of runoff; another part evaporates into the upper atmosphere; and the remaining portion increases the moisture content of the soil and seeps into the depths of the earth. It feeds the groundwater through the pores and cracks into the soil. Thus, different leaching from the soil of one capacity to the other depends on the renewal of aquifers or the so-called nutrition (Recharge) as a result of several factors. This includes soil properties, geological composition, rainfall and vegetation, and others. It can calculate the amount of water leaked into the ground in the study area based on the amount of rainfall during the period studied between 1980 to 2015. However, this amounted to approximately $149.28 \mathrm{~mm}$ (Masarweh, 2015) as shown in the equation below (Darwish, 2014):

The amount of annual rainfall in an area $=$ the amount of rainfall rate/mm * space that region $\mathrm{km} * 1000$. $=149.28 * 2506.61 * 1000=374.2 \mathrm{~m} \cdot \mathrm{m}^{3}$. 
Several studies on the desert areas, similar to the nature of the climate of the study area to determine absorption capacity and groundwater recharge, have been performed. The estimated increase in desert areas is around $6 \%$ of the total falling water annually. Thus, it is possible to estimate the leakage amount of water into the ground through the following equation (Darwish, 2014):

The amount of infiltration to the ground in an area falling = (annual rainfall rate/ $\mathrm{mm}) *$ ( area of the region $/ \mathrm{km}$ ) * $1000 *$ (Percentage of infiltration).

$=149.28 * 2506.61 * 1000 * 6 \%=22.45 \mathrm{~m} \cdot \mathrm{m}^{3} /$ year.

\section{Conclusion}

1. Suffer Soil Basin: In general, the Wadi Hasa soil basin suffers from water deficit at varying times throughout the year.

2. Water balance results showed that most of the excess water is concentrated in the western and northern regions. Also, regions which are located at high altitudes in the Mazar and Aabor stations did not exceed the area (30\%) of the basin.

3. The aquaculture is surplus in the winter, while the basin is suffering from a clear water deficit, especially in the summer months.

4. It is possible to divide the water balance during the water year into two:

A. Separate Aqueous Surplus: It starts from the month of December and continue until the month of March for the station Aabor. It is the month of January to the month of March for the station Mazar. During this time, the soil regains their lost moisture during the dry season. After saturation, there is surplus water on the surface of the earth in the form of Solvents. Also, part of the water seeps into the ground to fill the groundwater deficit, and feed the springs and wells in the study area.

B. Separating the Water Deficit: It starts from April until the month of November, and it exceeds the amount of the monthly amount of evaporation of precipitation.

5. The amount of water deficit which is peaked in July and August is where the two ends are in the soil of an aqueous stock.

6. The quantity of Potential evapotranspiration peak during the summer months.

\section{Recommendations}

1. Increase the number of measuring stations to facilitate good and regular water distribution in Jordan in order to study climate and hydrological well. This is in addition to facilitating access to data and the 
provision of accurate data to the researchers, such as data climatic and soil data and plants.

2. Expansion of the rain water harvesting, water investment, through the establishment of excavations.

3. The researcher dams storage in the northwestern section, to book the amount of rainfall, especially as it receives the amount of rain. This is done by taking into account the important positions to cover the deficit in the summer. Also, it creates water projects on paved surfaces which is characterized by a deaf layer and a moderate gradient.

4. The study also recommends the reduction of the effects of water deficit in the study area for agricultural production, especially in the summer months. The study area receives significant amounts of rain per year, and is characterized by a stock aqueous. Thus, it must work to maintain and regulate irrigation methods and development in the region. In addition, it should work on the development of agriculture method.

\section{References:}

1. Abu Saleem A. Hane (2009). Estimation of water balance Components in the Hasa Basin With Gis Based - Wetspss model, Degree of Master of science in water recourses management and Environmental, Al- Balqa applied University, Amman, Jordan.

2. Al.balawi falah arqoub (2003). Hydrological and hydrogeological study of wadi wala catchments area, degree of master, university of Jordan, Amman, Jordan.

3. Al- Jabari, S. Abushark, M. and Al-Mimi, Z. (2009). Estimation of Runoff for Agricultural Watershed sing SCS Curve Number and GIS, Thirteenth International Water Technology ,IWTC13, Hurghada, Egypt, 1213-1228.

4. Annanzeh, Ali (1996 m). Water balance based on rainfall amounts and potential evapotranspiration in the basin of the Wadi Karak, Mutah University Journal for Research and Studies, Jordan, Vol 11, No 5.

5. Darwish, Izz el-Deen Gomaa (2014). Water balance of the soil and its relationship to agricultural production (Sulaimaniyah province a model for the study), Journal of the Faculty of Arts, Issue 99, pp 466506.

6. Jasrotia, A.S and Majhi, A. (2009). Water Balance Approach for Rainwater Harvesting Using Remote sensing and GIS Techniques, Journal of Jammu Himalaya , India, water Resources Manage, 23, 3035-3055.

7. Masarweh, T, (2015). The assessment of water resources and their effects on the environment in the basin of the valley Hasa using 
applications geographic information system, unpublished $\mathrm{PhD}$ thesis, University of Jordan, Amman, Jordan.

8. Ministry of Agriculture (1993). National soil map and land Use project the soils of Jordan, level 1, Reconnaissance soil survey, volume 2 Jordan soil survey and land Research centre.

9. Suleiman, A. (2006). One Dimensional Soil Water Dynamics Model (SWDM-1D), The Code of the SWDM-1 is Written By: Coleman,E. Qasem, M. Mohammad, B. (Ayman.suleiman @ ju.edu.jo).

10. The Ministry of Water and Irrigation, (2013) reports and bulletins.

11. Thornthwaite, C.W and Mather , J.R (1957). Instructions and Tables for Computing potential Evapotranspiration and Water Balance Cenetron, Newjersy , USA, Laboratory of Climatology.

12. Thornthwaite, C.W and Mather , J.R. (1955). The Water Balance, Publication in Climatology, Cenetron, Newjersy , USA, Laboratory of Climatology,

13. Victoria, D.C. Santiago, A.V. Ballester, M.V.Pereira, A.R.Victoria, R.L. Ri chey, J.E. (2007). Water Balance for the Ji-Paran, Western Amazon, Using A simple Method through Geographical Information Systes and Remote Sensing, Earth Interactions ,11(5),1-22Ward, R.C.(1967), Principle of Hydrology, Berkshire, England McGraw Hill Pubishing company limited Maidenhead .

14. Shehadeh, Naaman (1983). The Climate, 2nd, Press typical Anoor, Amman, Jordan.

15. Usaid, Institute WDM in Jordan , 2010, Development : Role of Remote sensing and Geography Information system. 